\title{
Minority Community Resilience and Cultural Heritage Preservation: A Case Study of the Gullah Geechee Community
}

\author{
Ladan Ghahramani ${ }^{1}$, Katelin McArdle ${ }^{1}$ and Sandra Fatorić ${ }^{2, *}{ }^{10}$ \\ 1 College of Natural Resources, North Carolina State University, 2820 Faucette Dr., Campus Box 8004, \\ Raleigh, NC 27695, USA; Lghahra@ncsu.edu (L.G.); kati.mcardle@outlook.com (K.M.) \\ 2 Faculty of Architecture and the Built Environment, Delft University of Technology, Julianalaan 134, \\ 2628 BL Delft, The Netherlands \\ * Correspondence: s.fatoric@tudelft.nl; Tel.: +31 (0) 638-070-750
}

Received: 23 February 2020; Accepted: 12 March 2020; Published: 13 March 2020

\begin{abstract}
The Gullah Geechee community of the south-eastern United States endures today as a minority group with a significant cultural heritage. However, little research has been conducted to explore this community's resilience in the face of climate change and other environmental impacts. The database Web of Science was searched and 109 publications on the Gullah Geechee community were identified. Using quantitative and qualitative methods, we analyzed the publications to identify patterns and primary research themes related to the Gullah Geechee community's resilience. Findings revealed that Gullah Geechee's cultural heritage is vulnerable to climatic and societal changes, but can also be a source for enhancing community resilience and promoting more sustainable community-led heritage and tourism developments. A framework is proposed for building community resilience in the context of minority and/or marginalized communities (e.g., Gullah Geechee). This study highlights the urgent need to not only better understand and incorporate a community's economic dimensions and losses in various decision- and policy-making processes but also their cultural and social dimensions and losses. This systematic analysis can help inform both heritage preservation and community-led tourism practices and policies related to the Gullah Geechee community, as well as help direct new research efforts focusing on minority and/or marginalized community resilience.
\end{abstract}

Keywords: climate change policy; climate adaptation planning; community-led tourism; cultural heritage management; historic preservation; intangible heritage; marginalized group; loss and damage

\section{Introduction}

The Gullah Geechee are descendants of people who were captured along the western coast of Africa and enslaved on rice-producing plantations in the Lowcountry, primarily in Georgia and South Carolina, United States. The Gullah Geechee community continued to inhabit and farm these coastal plains and Sea Islands after slavery was abolished by the ratification of the 13th Amendment to the United States Constitution in 1865 [1]. Until the 1950s, when bridges were built to connect the Sea Islands to the mainland, the islands were more difficult to access, which resulted in the development of a language, identity, and way of life that was unique to the Gullah community [2]. It is estimated that fewer than 500,000 people speak the Gullah language today [3].

Although members of the Gullah Geechee community are not indigenous to the U.S., their language, traditions, experiences, and the ways in which their culture is interpreted share some parallels with other, often minority and marginalized populations in the U.S. The Gullah Geechee are unique and distinguished from the larger African American population. Before the construction of 
modern bridges allowing regular and convenient access, Gullah Geechee people residing in the Sea Islands were isolated and able to maintain their culture in close-knit, rural communities [4]. Over the last few decades, the Gullah Geechee community faced cultural displacement from threats of development, climate change, and access to natural resources, placing at risk the heritage that they contribute socio-culturally and economically to the region of the south-eastern U.S., while bringing forth a necessity for resilience, and shaping the culture into its present iteration.

An iconic craft tradition of the Gullah is the sweetgrass basket, which is made using a traditional practice and woven from local grasses [5]. Basket makers face threats to this livelihood, including limited access to natural areas from which they harvest raw materials, as well as barriers to their ability to set up their stands and wares along increasingly busy and developed roadways [6]. The sweetgrass basket, as an intangible heritage, has been passed down for generations, and depends upon the tidal marshes from which to harvest materials. Furthermore, coastal development and climate change impacts, such as sea-level rise, more frequent storms and hurricanes, and increased coastal erosion are likely to further impact their livelihoods and unique culture [7]. As argued by the Gullah Geechee's Chieftess and Head-of-State, Queen Quet (Marquetta Goodwine), "Without the ability to continue our cultural traditions on the land and the sea, we would not be able to continue to live in the healthy, balanced manner that is central to traditional Gullah Geechee culture" (https://www.theguardian.com/environment/2019/oct/23/gullah-geechee-distinct-us-culturerisks-losing-island-home-to-climate-crisis). This demonstrates the need to take urgent community-led climate change adaptation measures against more severe and frequent environmental or climate change hazards [8-11].

As the acting management agency of some of the country's most well-known natural and cultural heritage, the National Park Service (NPS) is responsible for protecting, maintaining, and interpreting heritage sites that have close connections to various ethnic and cultural groups. In 2006, the U.S. Congress established the Gullah Geechee Cultural Heritage Corridor, which occupies the coastal area from Wilmington, North Carolina to Jacksonville, Florida. In 2013, the Gullah Geechee Cultural Heritage Corridor Management Plan was approved by the federal government, and includes three implementation tiers: education, documentation, and preservation - to which partnerships for projects and programs within the scope of the corridor must adhere. It also includes interpretive themes that partners and sites are encouraged to incorporate into their work, such as "Cultural and Spiritual Expression" and "Connection with the Land" [1].

Educating the public on perceived historic wrongs to minority or marginalized groups is a challenging task, requiring insight and sensitivity to historical contexts, as well as to the ongoing struggles of minority and/or marginalized populations. Over the last decade, the NPS has focused on the Gullah cultural group, publishing an extensive report examining the cultural heritage of this community. Findings revealed several themes that emerged as important to community members who were involved in the interview portion of the research, which covered topics such as family history, educational activities, heritage preservation, and cultural pride [12]. The report's conclusion stated that, "Research for the sake of research is no longer acceptable; therefore, all future research within the Sea Islands should be approached with an agenda for contributing, in some way, to local communities" [12] (p. 418).

Therefore, documenting and raising awareness for the preservation of this unique community's cultural heritage needs to be prioritized. Our study contributes to informing current and future policy-making efforts that promote community resilience tied to their intangible cultural heritage, such as those involving the Cultural Heritage Corridor, as well as to an academic understanding of the societal, environmental, and climate change threats that the Gullah Geechee may face. The term "community resilience" is used in this paper to mean an ability to anticipate, learn from, and cope with past perturbations, while integrating this knowledge to reduce vulnerability to future risks and lessen the likelihood of disaster. This requires a community to draw upon social connections, capacity, resources, and natural or built capital to rebound ("or bounce back) from and reduce future risks [13]. 
The aim of this paper is to apply a systematic literature review methodology to critically explore, identify, and characterize the ways in which Gullah Geechee community resilience is represented through published research work, to provide a baseline for future research, and to inform and support practice and policy.

\section{Materials and Methods}

\subsection{Data Collection and Analysis}

A systematic literature review methodology [14] was used to identify and discuss the scientific publications focusing on Gullah Geechee community. A systematic literature review uses a set of transparent and replicable scientific methods to identify, categorize, and synthesize the relevant studies to answer the research questions, identify research gaps, provide recommendations for future research [15,16], as well as give useful input to policy and practice [17]. While systematic literature reviews are increasingly used in the social sciences, to the best of the authors' knowledge there is no systematic or other type of literature review focused on reporting and discussing Gullah Geechee community-related issues. Such a systematic review differs from traditional reviews in its use of clearly defensible criteria for the selection of publications rather than ad hoc selection of publications (which are often subjected to undisclosed bias) [16].

The online scientific database Web of Science, an archive encompassing the longest period of published scientific publications (since 1900) covering most scientific disciplines, was searched in March 2019 to identify existing peer-reviewed literature related to Gullah Geechee people. The keyword set used for the search was "Gullah" OR "Geechee". The search focused on literature published between 1900 and the end of December 2018 without applying a language restriction.

The search retrieved 226 publications, all of which were published in English. These publications were screened based on title, keywords, and abstract to evaluate suitability for inclusion in the final review. We defined two exclusion criteria for the 226 publications: (1) Full books, book reviews, meeting and/or conference abstracts, letters, editorial materials, blog and magazine articles, and movies; and (2) publications that were not fully focused on research of the Gullah Geechee community. Articles, proceedings papers, and book chapters were included in the final review. Following publication screening and the application of exclusion and inclusion criteria, 109 publications were retained for extensive full-text review. The limitation of this study is that it only focuses on scientific publications, while excluding other sources for documenting Gullah Geechee research, such as technical reports, white papers, policy documents, magazines and newsletters.

The number of included and excluded publications for this systematic review and the process for determining the articles for analysis is shown in Figure 1. 


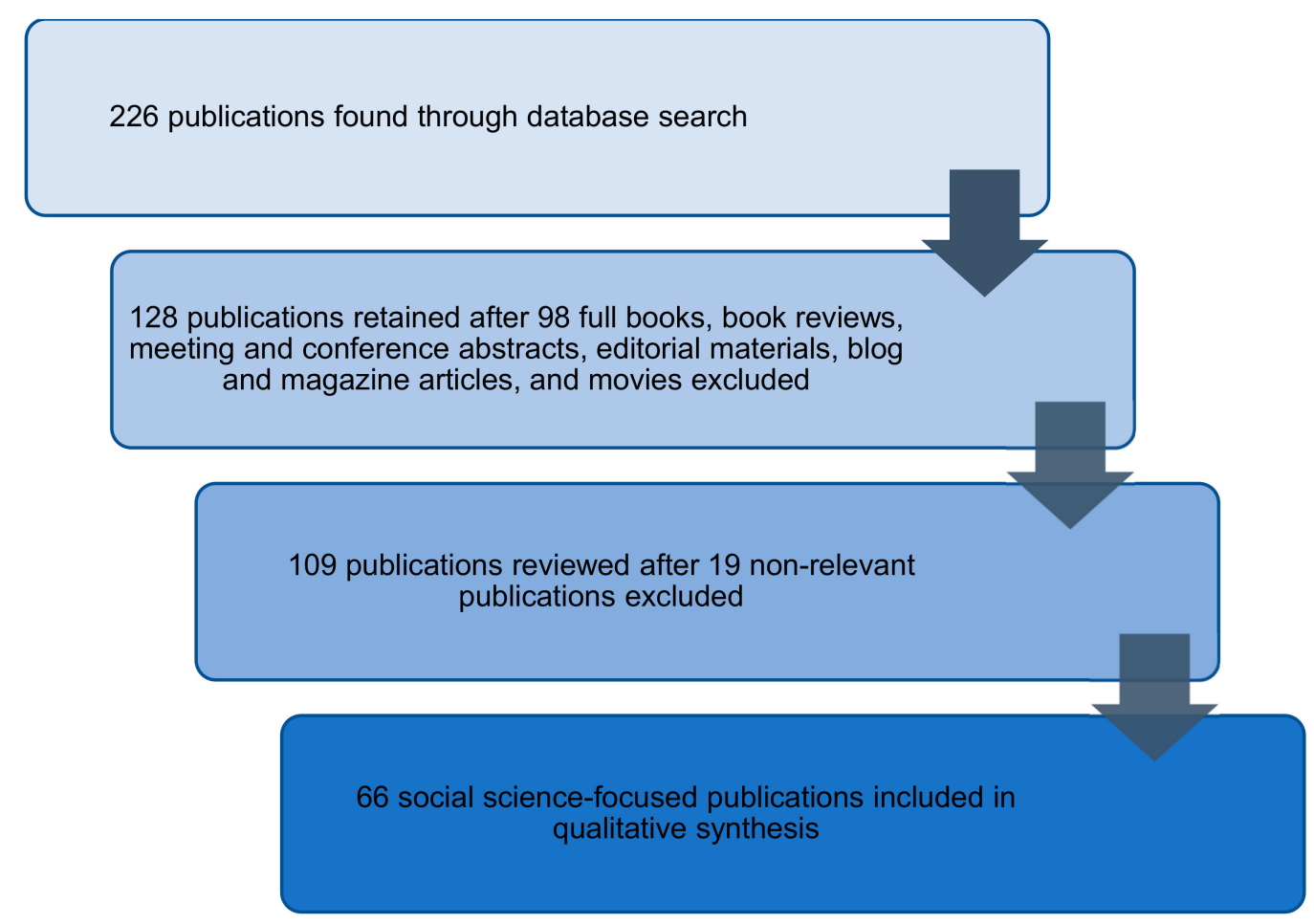

Figure 1. Flow diagram of the exclusion criteria and selection process.

A questionnaire was then created to survey the selected publications. For each publication, we analyzed nine research questions that were formulated in terms of our research objectives: (1) In which year was the publication published? (2) What is the format of the publication? (3) What is the name of the journal? (4) What is the main research discipline of the publication? (5) What type(s) of research methods are used? (6) Which geographic area is the subject of the article? (7) Which study population in terms of age is the subject of the article? (8) Which study population in terms of gender is the subject of the article? (9) What is the main research theme found in the publication? and (10) What makes a community resilient?

Data from all 109 publications were entered into a Microsoft Excel spreadsheet, and both deductive and inductive coding was performed. Coding categories were created and organized around the themes established by the questionnaire. Descriptive statistics were used to summarize quantitative trends in the publications with categories guided by the questionnaire. Qualitative analysis was performed using exploratory, thematic content analysis [18] to identify key themes of Gullah Geechee research within the selected publications.

\subsection{The Case Study: Gullah Geechee Community}

Gullah Geechee are direct descendants of Africans who were enslaved for generations in the U.S. Today, this community is settled along the coastal counties of North Carolina, South Carolina, Georgia, and Florida. The nature of their enslavement on isolated islands along the Atlantic coastline created an intangible cultural heritage that is visible in the unique tradition, arts, crafts, cuisine, music, and Creole language [1]. In this paper, intangible heritage is defined as traditions or living expressions inherited from the ancestors and passed on to descendants, such as oral traditions, performing arts, social practices, rituals, festive events, knowledge and practices concerning nature and the universe, or the knowledge and skills to produce traditional crafts [19].

Gullah Geechee are speakers of one of the few African American Creole languages of the U.S. that is recognized as an important intangible heritage. The Gullah Geechee language exists primarily in its oral form and it is considered an endangered cultural heritage. In addition to their rich oral and literary 
traditions (such as the Uncle Remus tales), the Gullah Geechee brought with them a variety of distinct arts and crafts like metalwork, quilting (e.g., story quilts), net-making, textile-making, basket-making, woodcarving, music, food (including items that came from Africa via the slave trade, such as okra, rice, yams, sorghum, and peanuts), and folklore. These traditions took on new meanings in the context of slavery and combined with elements from the setting of the American south. Today, these crafts not only have the potential to be marketable and profitable products and experiences, but are important and visible symbols for the continuation of Gullah Geechee history, cultural awareness and identity, and livelihood [12].

Some important steps in recognizing the contributions of Gullah Geechee community (African Americans) to American culture and history, as well as in interpreting their story and preserving their heritage was the establishment of the Gullah Geechee Cultural Heritage Corridor. The Corridor represents a significant story of local, regional, national, and global importance [1], thus community-led management of Gullah's cultural heritage is not only important for sustainable safeguarding of this community's cultural identity and livelihoods but it is also a human rights issue [20].

The knowledge-based sector such as education, health, and social services is the most important economic sector with respect to the number of employees and income, together with heritage tourism, arts, entertainment, recreation (hunting and fishing), accommodation, and food services. Many Gullah people are also economically tied to natural resources. For example, the income and livelihood of farmers, sweetgrass basket makers, fishermen, and crabbers depend on nature and wildlife [1]. This highlights the importance of healthy and resilient ecosystems particularly under anthropogenic climate change in maintaining the quality and way of life of the Gullah Geechee community. Although the Gullah community was historically challenged by slavery, economic distress, fluctuations in natural resources, and spatial development, this community is known for their resilience and adaptability to environmental, economic, and societal stressors [1]. Yet, given the unprecedented speed and scale of changing climate and associated impacts, new challenges in management and preservation of Gullah's cultural heritage will likely arise. Therefore, proactively designing and implementing community-led policy responses for climate change adaptation and preservation of their invaluable heritage should be done in a timely manner [8-11].

\section{Results and Discussion}

In this section, we first present and discuss findings about the general patterns of included publications. Then, we summarize findings from the systematic review in two main research themes focusing on building community resilience. These findings also broadly support the proposed conceptual framework.

\subsection{General Patterns}

A total of 109 publications on the Gullah were identified using the Web of Science database. Two main research lines emerged through an analysis of the 109 publications: a) health science ( $n=43$, $39 \%)$ and $b$ ) social science $(n=66,61 \%)$. The focus of this review was on socio-cultural themes, so this analysis focused on the 66 social science publications while examining some overall trends across all 109 publications.

There has been a growing body of research on the Gullah community over the past eight decades, with an increase from seven publications published over the 40-year period of 1941 to 1980 to 102 publications published from 1981 to 2018. The earliest publication on Gullah in the Web of Science database was published in 1941 [21].

The 109 publications included 104 (95\%) peer-reviewed articles, along with four book chapters and one conference proceeding. Among the 66 social science publications, most results $(n=61,92 \%)$ were journals, while a few $(n=4,6 \%)$ were book chapters. One social science conference proceeding $(2 \%)$ was found. All 43 health science publications were in the form of journal articles. 
Seventy different journals were represented in the 109 results, with American Speech as the most frequently-occurring journal, with 15 published articles (14\%), indicating an emphasis on speech and language as an area of study. This was followed by Journal of Black Studies $(n=4,4 \%)$ and Journal of Pidgin and Creole Languages $(n=3,3 \%)$. Similarly, the most common publication within the social science category was American Speech $(n=15)$. In Figure 2, the analysis of social science publications by year and research method employed is shown.

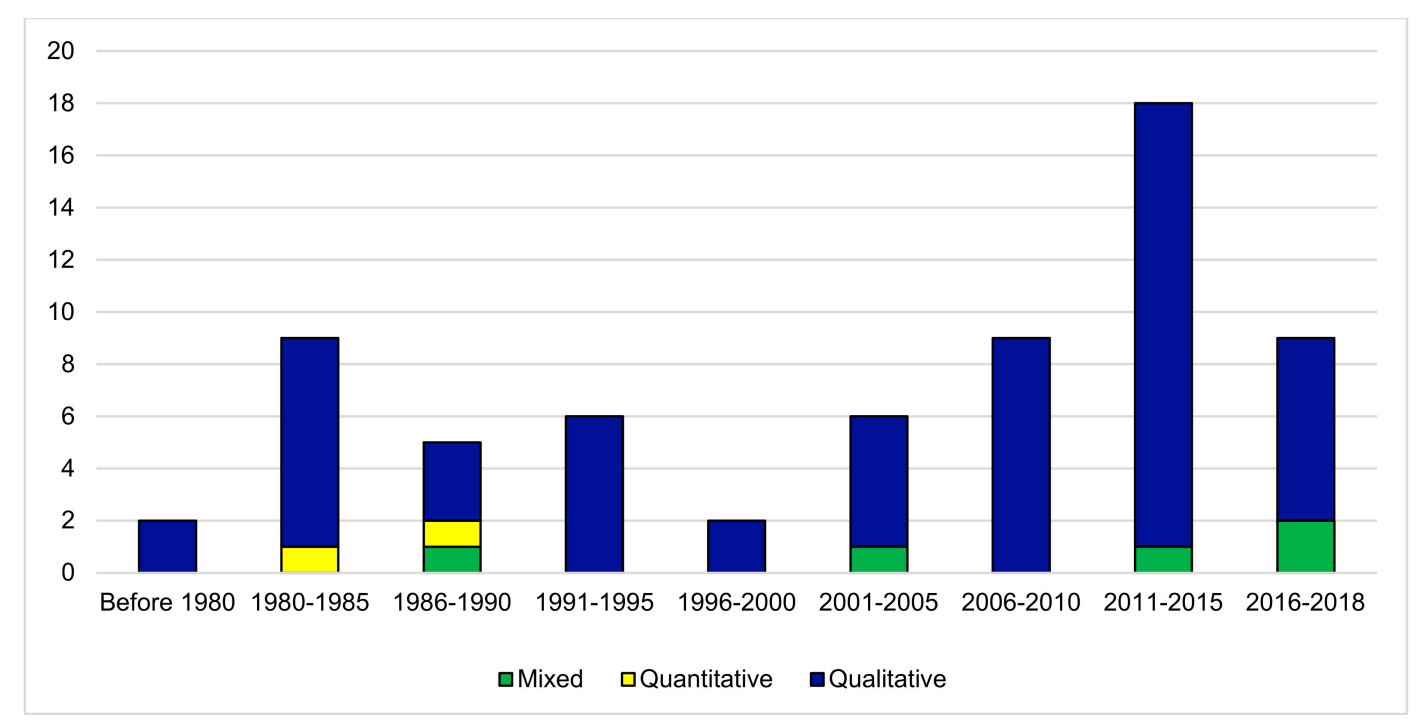

Figure 2. Number of social science publications $(n=66)$ per year sorted by research method used.

In terms of research area (Figure 3), the 66 social science publications focused on language ( $\mathrm{n}=35$, $32 \%)$, cultural heritage $(n=21,19 \%)$, history $(n=6,6 \%)$, tourism $(n=2,2 \%)$, and literature $(n=2,2 \%)$. Language and cultural heritage are two broad social science categories covering a diversity of topics. For example, Gullah cultural heritage is described as both tangible and intangible, including topics such as fishing culture (e.g., [22]), basket-making traditions (e.g., [5,23]), folk telling (e.g., [24-26]), conflict resolution (e.g., [25]), the marketplace (e.g., [27]), and cultural aspects of pregnancy (e.g., [28]). Language studies mainly focused on Gullah language distinctiveness, tracing the roots of this rich language and the current threats to its survival (e.g., [2,29-31]).

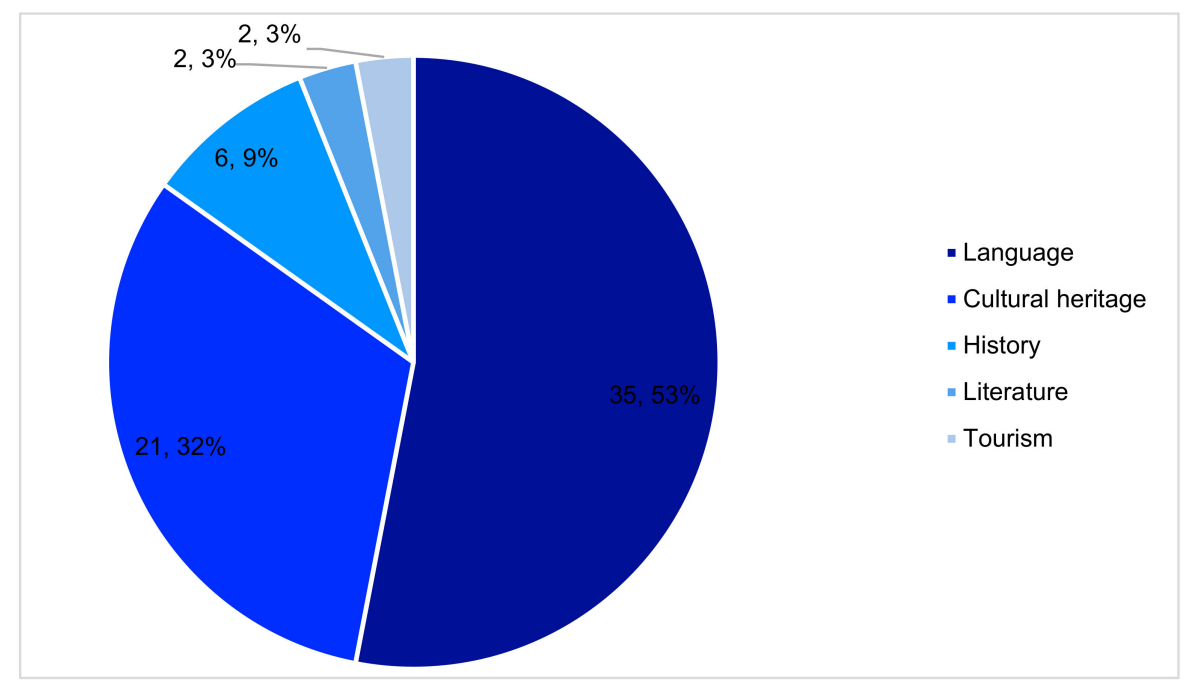

Figure 3. Research areas of social science publications $(n=66)$ per number of publication and percentage. 
Most of the social science publications employed a qualitative research method ( $n=59,89 \%$ ), while few used mixed $(n=5,8 \%)$ or quantitative methods $(n=2,3 \%)$. Methods used included qualitative, such as interviews (e.g., [32]), literature analysis (e.g., [33]), language analysis (e.g., [34]), mixed methods, such as speech analysis with coding and multiple regression analysis (e.g., [35]), and folknography (e.g., [25]); and quantitative methods, such as surveys (e.g., [36]).

In addition to traditional qualitative and quantitative research methods, some studies used more innovative approaches to study the Gullah community. These approaches included using the Afro-centric technique of implementing community justice instead of state-promoted justice strategies in communities of color in the United States [25]; ethnography for studying social and behavioral changes of Gullah community over time, e.g., sense of belonging [37], dynamic linguistic behavior [38], designing culturally sensitive interventions [39], incorporating migration, acculturation, and geographical isolation to explore patterns of cultural preservation [40], collaboration with the community advisory board to guide research design [39], and applying differential gene analysis to better understand health diseases [41].

About half of all 109 publications $(n=58,53 \%)$ focused on the Gullah living in South Carolina. A small number studied the Gullah community residing in Georgia $(n=3,3 \%)$. Many publications $(n=31,28 \%)$ focused on Gullah communities living in multiple locations, while some $(n=17,16 \%)$ did not specify the location of the study population. No studies identified North Carolina or Florida as a study location, despite these states being included in the Cultural Heritage Corridor. These findings are reflective of the geographic extent of the Gullah community, which is traditionally concentrated in the Sea Islands of South Carolina and Georgia [1].

\subsection{Main Research Themes}

\subsubsection{Enhancing Community Resilience through Community Capitals Preservation}

Emerging evidence shows that both tangible and intangible heritage have an invaluable role in fostering community resilience [42]. However, in the case of the Gullah Geechee, this is a complex and evolving situation. For example, heritage tourism is shown to have the potential to be both a positive and negative force, exacerbating some problems (such as fraudulent individuals posing as Gullah Geechee, and increased tension due to the profitability of tourism activities) while improving others (such as economic development), meaning that community resilience could be enhanced in some ways and compromised in others. Regardless, opportunity exists within local and state tourism offices to better showcase Gullah Geechee culture alongside other themes of the southeast and Sea Islands [43]. In addition, documentation of folklore that might otherwise be lost to history provides a legitimate source of linguistic data on early Gullah speech and dialect and representation of the culture, which could promote a sense of shared heritage and therefore foster community resilience. [26]. Preserving the Gullah's language and narratives as one of their main community capitals can empower these communities and sustain their position in American history [24]. Studies from other geographical contexts also found that attachment to intangible heritage can support in building community resilience. For instance, in the case of the indigenous Maori people (New Zealand), they were enabled to be resistant to assimilation pressure and natural hazards and played a fundamental role in building and maintaining community resilience [44]. Similarly, Esfehani and Albrecht [45] showed that intangible heritage can contribute to building community resilience while encouraging and promoting culturally and naturally sensitive behavior in tourism practice. Khakzad and Griffith [46], in their study on traditional fishing and associated heritage (e.g., memory, history, maritime landscape, fish houses), suggested that developing policies to promote and preserve fishing communities' traditional practices and way of life can foster their cultural identity and sense of place and in turn increase community resilience. In addition, Parsizadeh et al. [47] documented that elements of the cultural landscape were perceived as having an important contribution in enhancing sense of place and building communities' resilience during earthquake disaster recovery. Yet, limited research has been conducted to identify if 
and how does climate change create risks to diverse intangible heritage and which adaptation measures can reduce those risks in the context of developed as well as in developing countries [8,10].

Despite a slow but growing body of research emphasizing the importance of the Gullah's intangible heritage in enhancing their community resilience, only a few studies focused on their social and climate change vulnerability (e.g., $[5,16,22,23]$ ) or approaches for building resilience through preservation (e.g., [7,24,48]). For instance, scholars documented the need to better integrate the Gullah community's place attachment, sense of place, and intangible heritage into climate adaptation planning and risk management [7]. Ellis et al. [22] discussed the impact of climate and societal changes on Gullah's fishing practices and fish consumption and the negative impact that these changes can have on community health. More practical and effective health communication strategies are necessary to promote sustainable and healthy fish consumption choices in Gullah community [22]. Furthermore, real estate and coastal development are shown to constrain access of Gullah Geechee's basket makers to the essential resources such as sweet grass, and have contributed to cultural displacement and poverty (e.g., [5,23]). Increasing cultural awareness was found to play an important role in instilling pride in Gullah speakers [29]. Informing the Gullah community and the public about the origin of the language can contribute to the revival and preservation of the Gullah language (e.g., [18,48]). Furthermore, whether the Gullah language is or is not disappearing from four coastal states should be explored more in future research. In particular, there is a need for more research on phonological aspects of the Gullah language [26].

Future research is warranted to understand social and cultural dimensions of the minority and/or marginalized community resilience and heritage preservation under changing climate beyond the economic aspects (e.g., economic valuation, cost-benefit analysis). This is especially relevant for minority or marginalized communities on the frontline of the climate crisis who often inhabit the land vulnerable to climate-related impacts (e.g., flooding, coastal erosion, drought) due to colonial practices of domination and dispossession of land [49]. To enhance resilience to climate change, we need first to advance in social equity, since the institutional systems that drive minority or marginalized communities' vulnerability to environmental or climatic change are rooted in the processes that generate social inequality [50-52]. We argue that to effectively build community resilience, it is not enough just to "bounce back" but rather, there should be a focus on how to "bounce forward" that advances the cultural, social, and environmental transformation of minority and/or marginalized communities and minimizes existing socio-cultural and economic inequities (e.g., property rights, zoning and redevelopment, housing unaffordability, displacement). Multi-level actors should understand the specific diversity issues of each community, document diverse local voices, plan for changing demographics of the area, build local capacity, and ensure that communities are involved in the decision-making processes from the beginning [50,53]. Previous research (e.g., [54-56]) suggested that policies that involve minority or marginalized communities for shared responsibilities and decision-making and have the full ownership of local institutions, such as tourism, are more likely to result in effective policies for heritage preservation and enhancing community resilience. Incorporating the spectrum of people's attitudes and values, traditional knowledge, and socio-cultural practices that are embodied in local community culture and heritage was suggested as a more inclusive and collective approach to disaster management and climate change resilience for the Gullah community as well as for other minority and/or marginalized communities $[7,49,53,57,58]$. In addition, empathic and emotional engagement with place can create cultural meaning and can embed the pro-environmental behavior in place-oriented norms and institutions [59]. Future research would benefit from longitudinal comparative case analysis (e.g., [60]) with other minority and/or marginalized communities to explore community resilience and understanding of the impacts of environmental or climatic change, as well as in terms of place-based or community-based heritage management or collective action for more sustainable tourism development. Such comparative research using methods and approaches from social science is critical for improving the credibility, defensibility, and social acceptability of decision making processes [61]. 
In this study, assessing strategies for eliminating poverty in the Gullah community was found to be of utmost importance [62]. Potential impacts of any development on cultural stability of the Gullah and community cohesion need to be assessed and measured [23]. As such, it is important to better understand drivers of inequalities [63] and how these, together with other social processes, shape the vulnerability of the Gullah Geechee community and aggravate risks to changing climate. Strengthening gender equality, particularly the adaptive capacity of Gullah Geechee's women, can help to enhance their community resilience and reduce vulnerability to climate change hazards. This systematic review revealed that while a small portion of the publications $(\mathrm{n}=11,17 \%)$ studied both female and male community members, a few publications $(n=2,3 \%)$ focused only on female participants. Hence, future studies should focus on fostering gender equality in research, as well as on improving social and economic infrastructure that would support building resilience of Gullah Geechee women and their intangible heritage and associated livelihoods (e.g., sustainable tourism practices) against climate change risks.

Many of the cultural aspects of Gullah people have direct implications for community-led tourism development in the area, though only two publications focused on this connection and the opportunities associated with that $[43,64]$. Boley and Johnson Gaither [43] found that tourism has contributed to social, economic, political, and psychological empowerment of Gullah Geechee through enhanced pride in being part of that community, new opportunities for community members to connect and collaborate on shared activities such as cultural festivals, and providing outlets for representation and engagement in political decision-making. On the other hand, Thomas [64] documented how a transition from agricultural to resort-oriented tourism industry affected the economic, social, and cultural fabric of the Gullah Geechee community, including tourism, which has created a social and economic injustice related to low-wage labor and "serving-others" culture. Nevertheless, McArdle [65] reported that partnerships between community-based nonprofit groups and natural and cultural heritage site managers can provide opportunity to facilitate meaningful interpretation of Gullah culture, and building connections within the local area.

Prior work has also shown the importance of community-led tourism for building the resilience of marginalized communities (e.g., [66-69]). For instance, the Basarwa, a marginalized ethnic group (Botswana) lost their land and access to their hunting resources as a result of the arrival of outsider groups and developments such as the establishment of a game reserve, which led to resource conflict and poverty among Basarwa community members. The government adopted a community-based tourism program to alleviate poverty through creating sustainable jobs for community members and enhance conservation through promotion of responsible use of natural resources to locals and visitors. Although tourism has brought socio-economic benefits to the Basarwa community, this program has performed poorly, as the local community members were only the participants in this program instead of being leaders and decision-makers [66]. Another study showed that tourism can be used as a narrative vehicle to influence tourists' perceptions about the impacts of climate change on Antarctica's cultural and natural resources by encouraging them to advocate and support heritage conservation efforts [67]. Tourism has also supported revitalization and recovery of rural heritage values in Trentino (Italy). This Italian community chose to utilize traditional knowledge and skills by using medical and aromatic plants as part of community-led tourism. Diverse community members and stakeholders participated in developing this tourism plan in order to capture and promote broader traditional knowledge and skills [68]. Furthermore, Tao and Wall [69] recommended sustainable tourism as an approach to diversify livelihoods for marginalized communities. This study documented how the Cou, an indigenous community in Shanmei (Taiwan), rely on tourism to diversify their economic activities and secure their livelihoods. In particular, the entrepreneurial opportunities created through tourism for members of the community strengthened their cultural identity and supported their income. We emphasize a need for developing policies that can draw on the strengths of community-led approaches for heritage preservation and more sustainable community-led tourism developments where communities are at the center of decision-making processes rather than passive participants. This 
could be an important step forward for minority and/or marginalized communities in safeguarding economic, socio-cultural, and environmental benefits of their intangible and tangible heritage against climatic and environmental hazards. As Maus [20] pointed out, more attention should be paid to the inclusion of human rights perspectives in questions related to community participation in selection, preservation, and interpretation of tangible and intangible cultural heritage.

Although we recognize that tourism can impact culture both positively and negatively, little research has been done on the impacts of marketing on the Gullah culture and heritage for attracting tourists [27]. Equally important, more research is needed to better understand tourism development and its economic benefits, such as job creation [64], and cultural benefits, such as the preservation of tangible and intangible Gullah $[23,43]$ and the heritage of other minority or marginalized communities (See Figure 4).

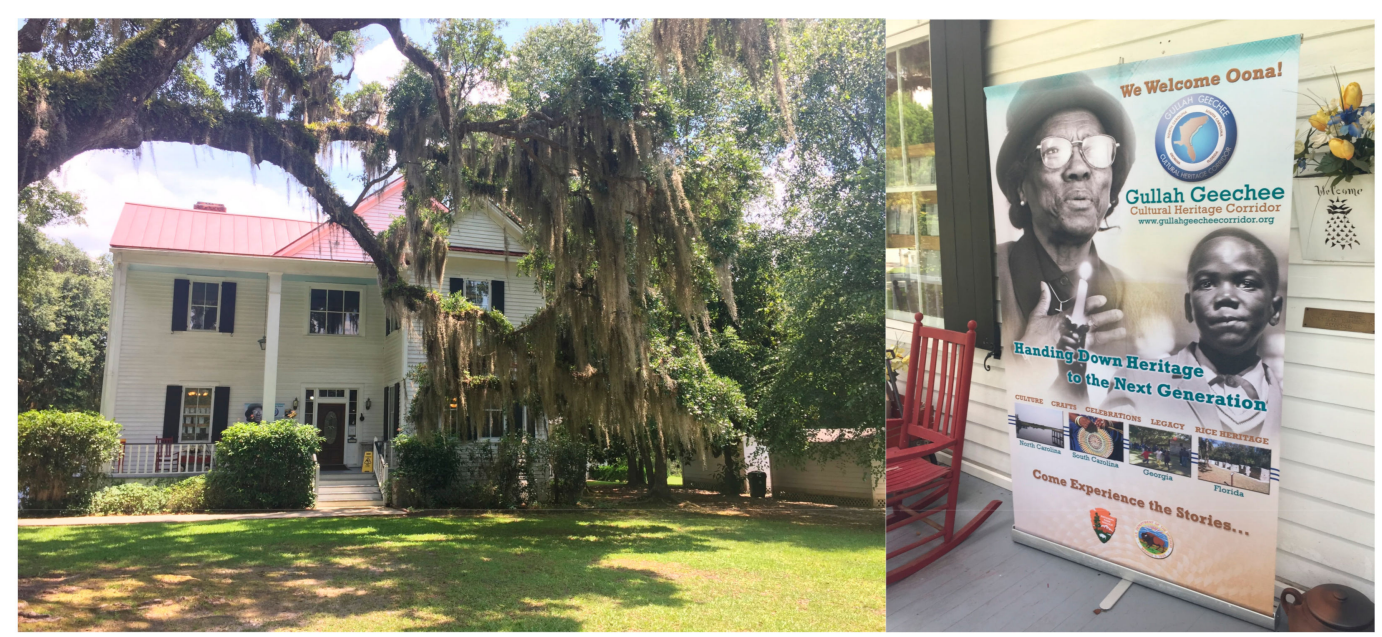

Figure 4. Promoting the Gullah Geechee Cultural Heritage Corridor at the Frampton Plantation House in Yemassee, South Carolina. Source: Authors.

\subsubsection{Enhancing Community Resilience through Improved Health Infrastructure}

Some publications across both the health and social science disciplines discussed implications related to Gullah community health, such as the development and implementation of culturally sensitive educational interventions and practical health communication strategies to promote healthy lifestyles and disease prevention (e.g., [28,39,70]). For instance, increasing access to healthcare services can reduce the progression of chronic periodontal disease among the Gullah community [71]. However, there are cultural implications and challenges involved with intervening in healthcare. As one study notes, the very economic prosperity brought by development-such as improved wages and access to healthcare-can bring an end to traditional ways of life that make up the Gullah culture [24]. Another study found that there is some confusion among Gullah in both rural and urban areas in distinguishing between fishing regulations and fish advisories, the latter of which is intended to inform consumers of seafood of potential levels of unsafe substances in fish, revealing a need for better communication of these measures intended to guard against unsafe consumption [22]. Due to the unique cultural group that the Gullah Geechee form, many of the health science studies in our results focused research on this group. For example, the Medical University of South Carolina (MUSC) in Charleston, SC, which is located toward the center of the Corridor, is currently conducting ongoing research focusing on the Gullah Geechee population. As one of the project descriptions on their website describes, the connection between the Gullah and their West African ancestors is unique culturally as well as medically. Our systematic analysis also showed that studying lupus in African Americans from the Sea Islands in South Carolina and Georgia is an important field of research which focuses on identifying and characterizing genetic and environmental factors that could result in the development of this autoimmune disease (e.g., [72,73]). Research is needed to understand the spatial and temporal 
complexity of a disproportionate health burden on minority and marginalized communities that transcend territorial boundaries, the responsibilities and capabilities of different multi-level actors across these systems, and the social, cultural, economic processes driving the health infrastructure and health injustice.

\subsection{Toward a Conceptual Framework}

In Figure 5 is shown a schematic cycle through which minority and/or marginalized community resilience could be built. As discussed in sub-Section 3.2, Gullah Geechee community has been facing inter-community conflicts ranging from gentrification, community displacement, and access to power and healthcare (e.g., $[5,23,63])$. Therefore, implementing conflict resolution strategies such as material or nonmaterial reparation (e.g., [25]) is an important step in creating resilience in such a minority community. Next, creating common goals, such as those around ideas of climate justice and addressing the underrepresentation of African Americans in the environmental movement [49], could help enhance sense of pride or community attachment amongst community members.

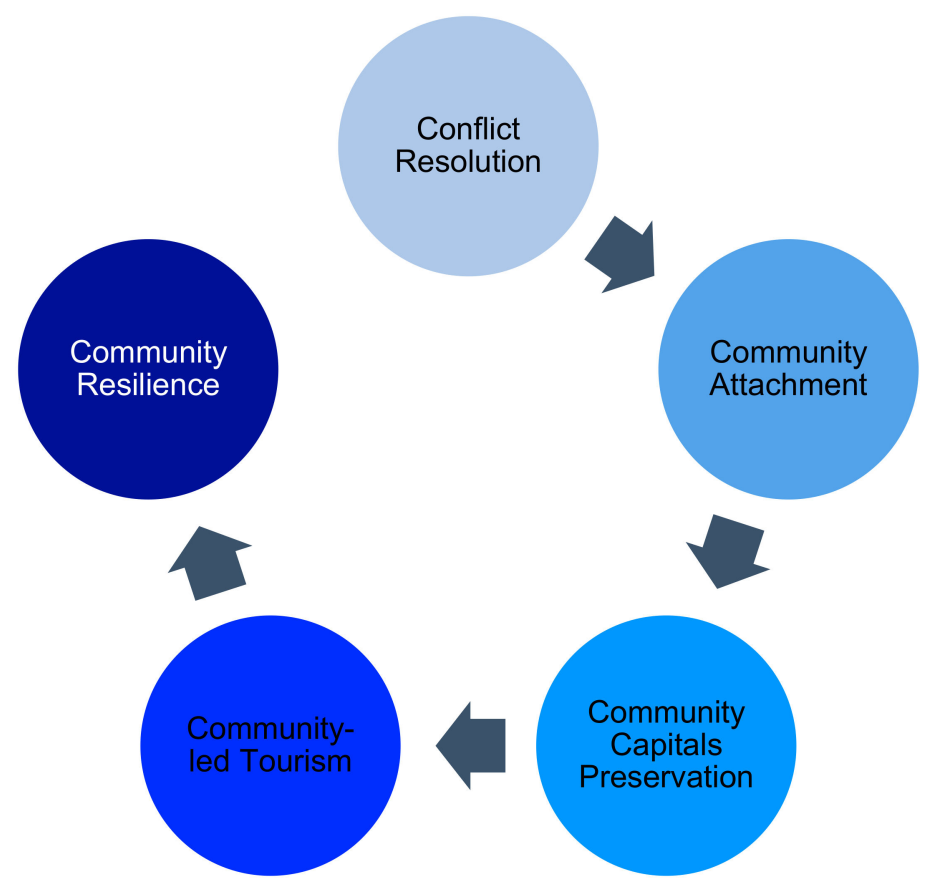

Figure 5. Illustration of the conceptual framework for building minority and/or marginalized community resilience.

Stronger community attachment can influence the protection or preservation of a community's human, social, cultural, and environmental resources (e.g., [32]), which in this framework are referred to as community capitals. Protecting community capitals is necessary for promoting community-led tourism, which is one of the economic development opportunities (e.g., [43]) identified in the present study. However, strong community engagement in developing and managing tourism strategies is necessary for them to be more equitable and sustainable. Lastly, community-led tourism can empower the community and enhance resilience. The resulting social, economic, environmental, and cultural strength and endurance (e.g., [7]) can help the Gullah community minimize both natural and human-caused threats such as climate change and societal marginalization. Importantly, the goal of enhanced community resilience should not be to simply help the community to "bounce back" after disruption or disaster, but to "bounce forward" to a more sustainable, inclusive, and democratic participation in the policy decisions that affect their cultural identity, way of life and 
knowing, and livelihoods. This framework can be considered when studying other minority or marginalized communities with similar characteristics and challenges in other geographic contexts.

\section{Conclusions}

This systematic review enables scholars to better understand what aspects of the Gullah community resilience have been studied, as well as identifies the areas where little or no research has been conducted. By exploring the link among the identified research themes, we propose a framework for building minority and/or marginalized community resilience through conflict resolution strategies, preservation of community capitals, and community-led tourism. Minority and/or marginalized communities can leverage their culture, traditional knowledge, and skills to develop and lead a tourism activity that contributes to a sustainable livelihood and community empowerment. The findings of this study open multiple doors for further research. As our framework is conceptual, future research should focus on its application (using empirical data) both in the context of the Gullah Geechee community and other minority or marginalized communities in other geographic contexts.

Despite the fact that climate change impacts have been threatening Gullah livelihoods, health, and cultural heritage, there is limited research in this area. Using more culturally appropriate and context-relevant approaches such as decision analytic and values-based approaches (e.g., [74-76]) research is needed into understanding environmental, social, and cultural vulnerabilities of the Gullah community in order to inform more effective and transparent community-led preservation and adaptation strategies for safeguarding their invaluable heritage. This study also highlights the need to better understand and incorporate not only economic dimensions and losses, but also equally important cultural and social dimensions and losses in various decision and policy-making processes. In this context, increased evidence-based research is needed to prepare minority and/or marginalized communities for potential loss and damage of their intangible heritage such as traditional practices, knowledge and skills, and way of life, for instance, by using an empathy-based approach [59], which can better emphasize connections between cultural identity and place, and generate a qualitative reframing of our understanding of community resilience in sustainability and climate change debates. As Magistro and Roncoli [77] highlighted, cultural meanings (and losses) are crucial dimensions not only of community-level understandings and responses but also of global scientific and political debates surrounding climate change.

Beyond academic implications, disseminating such knowledge to the Gullah community could help raise their self-awareness and promote self-identity. Such awareness among the Gullah community may increase their sense of belonging and pride, which can support in building their resilience against environmental and climatic changes. Resilient communities should also strive to meet sustainability requirements by reconciling environmental, socio-cultural equity, and economic demands. Furthermore, practitioners can use the findings of this study to work with the Gullah community and find financial and political support for sustainable and community-led tourism development. Due to their enduring relative isolation, and some resistance to outsiders, gaining access to primary-source information and data about the Gullah is often challenging [78]. Therefore, this study provides a first systematic analysis of the scientific literature on this community, as well as provides some insights as to what research approaches could be effective and embraced by the community.

In addition to scholars and the Gullah community, various decision makers and policymakers, who determine the management of the Gullah Geechee Cultural Heritage Corridor or other similar heritage sites, can benefit from gaining a more comprehensive perspective of understudied minority community resilience and importance of their intangible heritage preservation. In this context, increasing the awareness of the importance of safeguarding intangible heritage (and not just tangible heritage such as historic buildings, archeological sites, and historic landscapes) such as traditional knowledge, skills, and techniques and integrating those with scientific information can support more inclusive, robust, and transparent decision- and policy-making processes [9,10,57,58]. Furthermore, advancing 
equity and social and climate justice should be integrated into cross-sectoral community resilience and heritage preservation policy responses.

In the meantime, we hope our study will inspire other researchers and activists to recognize and increase their understanding of the intersection of community resilience and intangible heritage preservation under environmental or climatic changes globally, and engage minority and marginalized communities in dialogue on how to safeguard their irreplaceable cultural, social, environmental, and economic resources.

Author Contributions: All authors contributed to the study conception and design. All authors performed data collection and analysis. The first draft of the manuscript was written by K.M., while L.G. and S.F. critically revised and edited the manuscript. All authors have read and agreed to the published version of the manuscript.

Funding: This research received no external funding.

Conflicts of Interest: The authors declare no conflict of interest.

\section{References}

1. Gullah Geechee Cultural Heritage Corridor Commission. Gullah Geechee Cultural Heritage Corridor Management Plan; National Park Service: Denver, CO, USA, 2012.

2. Smalls, K.A. "We had lighter tongues": Making and mediating Gullah/Geechee personhood in the South Carolina Lowcountry. Lang. Commun. 2012, 32, 147-159. [CrossRef]

3. Mufwene, S.S. The ecology of Gullah's survival. Am. Speech 1997, 72, 69-83. [CrossRef]

4. Jarrett, C.W.; Lucas, D.M. Introducing folknography: A study of Gullah culture. In Proceedings of the 65th Annual Meeting of the Rural Sociological Society, Chicago, IL, USA, 14-18 August 2002.

5. Hart, Z.H.; Halfacre, A.C.; Burke, M.K. Community participation in preservation of Lowcountry South Carolina sweetgrass basketry. Econ. Bot. 2004, 58, 161-171. [CrossRef]

6. Grabbatin, B. Co-producing space along the sweetgrass basket makers' highway in Mount Pleasant, South Carolina. Southeast. Geogr. 2012, 52, 249-251. [CrossRef]

7. Brabec, E.; Chilton, E. Toward an ecology of cultural heritage. Chang. Time 2015, 5, 266-285. [CrossRef]

8. Fatorić, S.; Seekamp, E. Are cultural heritage and resources threatened by climate change? A systematic literature review. Clim. Chang. 2017, 142, 227-254. [CrossRef]

9. Fatorić, S.; Seekamp, E. Securing the future of cultural heritage by identifying barriers to and strategizing solutions for preservation under changing climate conditions. Sustainability 2017, 9, 2143. [CrossRef]

10. International Council on Monuments and Sites (ICOMOS). Future of Our Pasts: Engaging Cultural Heritage in Climate Action. Available online: https://indd.adobe.com/view/a9a551e3-3b23-4127-99fd-a7a80d91a29e (accessed on 27 February 2020).

11. Rockman, M.; Morgan, M.; Ziaja, S.; Hambrecht, G.; Meadow, A. Cultural Resources Climate Change Strategy; National Park Service: Washington, DC, USA, 2016.

12. National Park Service. Low Country Gullah Culture Special Resource Study and Final Environmental Impact Statement; National Park Service: Atlanta, GA, USA, 2005.

13. Albright, E.A.; Crow, D.A. Capacity building toward resilience: How communities recover, learn, and change in the aftermath of extreme events. Policy Stud. J. 2019. [CrossRef]

14. Petticrew, M.; Roberts, H. Systematic Reviews in the Social Sciences: A Practical Guide; Wiley Blackwell: Oxford, UK, 2006.

15. Pawson, R.; Greenhalgh, T.; Harvey, G.; Walshe, K. Realist review-A new method of systematic review designed for complex policy interventions. J. Health Serv. Res. Policy 2005, 10, 21-34. [CrossRef]

16. Berrang-Ford, L.; Pearce, T.; Ford, J.D. Systematic review approaches for climate change adaptation research. Reg. Environ. Chang. 2015, 15, 755-769. [CrossRef]

17. Macura, B.; Suškevičs, M.; Garside, R.; Hannes, K.; Rees, R.; Rodela, R. Systematic reviews of qualitative evidence for environmental policy and management: An overview of different methodological options. Environ. Evid. 2019, 8, 24. [CrossRef]

18. Thomas, J.; Harden, A. Methods for the thematic synthesis of qualitative research in systematic reviews. BMC Med. Res. Methodol. 2008, 8, 45. [CrossRef] [PubMed] 
19. United Nations Educational, Scientific and Cultural Organization (UNESCO). Convention for the Safeguarding of the Intangible Cultural Heritage. Available online: http://www.unesco.org/culture/ich/en/ convention (accessed on 27 February 2020).

20. Maus, S. Hand in hand against climate change: Cultural human rights and the protection of cultural heritage. Camb. Rev. Int. Aff. 2014, 27, 699-716. [CrossRef]

21. Bascom, W.R. Acculturation among the Gullah Negroes. Am. Anthropol. 1941, 43, 43-50. [CrossRef]

22. Ellis, J.H.; Friedman, D.B.; Puett, R.; Scott, G.I.; Porter, D.E. A qualitative exploration of fishing and fish consumption in the Gullah/Geechee culture. J. Commun. Health 2014, 39, 1161-1170. [CrossRef]

23. Grabbatin, B.; Hurley, P.T.; Halfacre, A. "I still have the old tradition": The co-production of sweetgrass basketry and coastal development. Geoforum 2011, 42, 638-649. [CrossRef]

24. Campbell, E.S.; Burton, O.V. Penn Center: A History Preserved; University of Georgia Press: Athens, GA, USA, 2014.

25. Jenkins, M. Gullah island dispute resolution. J. Black Stud. 2006, 37, 299-319. [CrossRef]

26. Troike, R.C. Assessing the authenticity of Joel Chandler Harris's use of Gullah. Am. Speech 2010, 85, $287-314$. [CrossRef]

27. Joseph, J.W. Meeting at market: The intersection of African American culture, craft, and economy and the landscape of Charleston, South Carolina. Hist. Archaeol. 2016, 50, 94-113. [CrossRef]

28. Phillips, W. Cravings, marks, and open pores: Acculturation and preservation of pregnancy-related beliefs and practices among mothers of African descent in the United States. Ethos 2005, 33, 231-255. [CrossRef]

29. Jones-Jackson, P. Contemporary Gullah speech: Some persistent linguistic features. J. Black Stud. 1983, 13, 289-303. [CrossRef]

30. Klein, T.B. African sounds in Gullah Geechee and on middle Caicos. Black Sch. 2011, 41, 22-31. [CrossRef]

31. Moody, S. New perspectives on African American English: The role of Black-to-Black contact. Eng. Today 2015, 31, 53-60. [CrossRef]

32. Beoku-Betts, J.A. We got our way of cooking things: Women, food, and preservation of cultural identity among the Gullah. Gender Soc. 1995, 9, 535-555. [CrossRef]

33. McNeil, E. The Gullah seeker's journey in paule marshall's "praisesong for the widow". MELUS 2009, 34, 185-209. [CrossRef]

34. Campbell, E.S. Gullah Geechee culture: Respected, understood and striving: Sixty years after lorenzo dow turner's masterpiece, Africanisms in the Gullah Dialect. Black Sch. 2011, 41, 77-84. [CrossRef]

35. Rickford, J.R.; Handler, J.S. Textual evidence of the nature of early Barbadian speech, 1676-1835. J. Pidgin Creole Lang. 1994, 9, 221-255. [CrossRef]

36. Jones-Jackson, P. On decreolization and language death in Gullah. Lang. Soc. 1984, 13, 351-362. [CrossRef]

37. Brown, K.L. Ethnographic analogy, archaeology, and the African diaspora: Perspectives from a tenant community. Hist. Archaeol. 2004, 38, 79-89. [CrossRef]

38. Troike, R.C. The earliest Gullah/AAVE texts: A case of 19th-century mesolectal variation. Atlantic 2003, 18, 159-229. [CrossRef]

39. Leite, R.; Hudson, C.; West, L.; Carpenter, E.; Andrews, J.O. Assessment of oral health needs and barriers to care in a Gullah Community: Hollywood smiles. Prog. Community Health Partnersh. 2013, 7, 201-208. [CrossRef] [PubMed]

40. Adrianto, I.; Wang, S.; Wiley, G.B.; Lessard, C.J.; Kelly, J.A.; Adler, A.J.; Glenn, S.B.; Williams, A.H.; Ziegler, J.T.; Comeau, M.E.; et al. Association of two independent functional risk haplotypes in TNIP1 with systemic lupus erythematosus. Arthritis Rheum. 2012, 64, 3695-3705. [CrossRef] [PubMed]

41. Morris, E.E.; Amria, M.Y.; Kistner-Griffin, E.; Svenson, J.L.; Kamen, D.L.; Gilkeson, G.S.; Nowling, T.K. A GA microsatellite in the Fli1 promoter modulates gene expression and is associated with systemic lupus erythematosus patients without nephritis. Arthritis Res. Ther. 2010, 12, R212. [CrossRef] [PubMed]

42. Wiggins, M. Eroding paradigms: Heritage in an age of climate gentrification. Chang. Time 2018, 8, 122-130. [CrossRef]

43. Boley, B.B.; Johnson Gaither, C. Exploring empowerment within the Gullah Geechee cultural heritage corridor: Implications for heritage tourism development in the Lowcountry. J. Herit. Tour. 2015, 11, 155-176. [CrossRef]

44. Pomeroy, A.; Tapuke, S. Understanding the place of intangible cultural heritage in building enduring community resilience: Murupara case study. N. Z. Sociol. 2016, 31, 183-204. 
45. Esfehani, M.H.; Albrecht, J.N. Roles of intangible cultural heritage in tourism in natural protected areas. J. Herit. Tour. 2018, 13, 15-29. [CrossRef]

46. Khakzad, S.; Griffith, D. The role of fishing material culture in communities' sense of place as an added-value in management of coastal areas. J. Mar. Isl. Cult. 2016, 5, 95-117. [CrossRef]

47. Parsizadeh, F.; Ibrion, M.; Mokhtari, M.; Lein, H.; Nadim, F. Bam 2003 earthquake disaster: On the earthquake risk perception, resilience and earthquake culture-Cultural beliefs and cultural landscape of Qanats, gardens of Khorma trees and Argh-e Bam. Int. J. Disaster Risk Reduct. 2015, 14, 457-469. [CrossRef]

48. Weldon, T. Gullah: Phonology. In A Handbook of Varieties of English, Phonology; Schneider, E.W., Burridge, K., Kortmann, B., Mesthrie, R., Upton, C., Eds.; Mouton de Gruyter: Berlin, Germany, 2004; Volume 1, pp. $393-406$.

49. Hardy, R.D.; Milligan, R.A.; Heynen, N. Racial coastal formation: The environmental injustice of colorblind adaptation planning for sea-level rise. Geoforum 2017, 87, 62-72. [CrossRef]

50. Fothergill, A.; Maestas, E.G.M.; Darlington, J.D. Race, ethnicity and disasters in the United States: A review of the literature. Disasters 1999, 23, 156-173. [CrossRef] [PubMed]

51. Ge, Y.; Yang, G.; Chen, Y.; Dou, W. Examining social vulnerability and inequality: a joint analysis through a connectivity lens in the urban agglomerations of China. Sustainability 2019, 11, 1042. [CrossRef]

52. Tschakert, P.; van Oort, B.; St. Clair, A.L.; LaMadrid, A. Inequality and transformation analyses: A complementary lens for addressing vulnerability to climate change. Clim. Dev. 2013, 5, 340-350. [CrossRef]

53. Jurjonas, M.; Seekamp, E.; Rivers III, L.; Cutts, B. Uncovering climate (in)justice with an adaptive capacity assessment: A multiple case study in rural coastal North Carolina. Land Use Policy 2020, 94, 104547. [CrossRef]

54. Calfucura, E. Governance, land and distribution: A discussion on the political economy of community-based conservation. Ecol. Econ. 2018, 145, 18-26. [CrossRef]

55. Chirenje, L.I.; Giliba, R.A.; Musamba, E.B. Local communities participation in decision-making processes through planning and budgeting in African countries. Chin. J. Popul. Resour. Environ. 2013, 11, 10-16. [CrossRef]

56. O'Keefe, E.; Hogg, C. Public participation and marginalized groups: The community development model. Health Expect. 1999, 2, 245-254. [CrossRef]

57. Chakraborty, S.; Gasparatos, A. Community values and traditional knowledge for coastal ecosystem services management in the "satoumi" seascape of Himeshima Island, Japan. Ecosyst. Serv. 2019, 37, 100940. [CrossRef]

58. Hayward, B.; Salili, D.H.; Tupuana'i, L.L.; Tualamali'i', J. It's not “too late": Learning from Pacific Small Island Developing States in a warming world. Wiley Interdiscip. Rev. Clim. Chang. 2020, 11, e612. [CrossRef]

59. Brown, K.; Adger, W.N.; Devine-Wright, P.; Anderies, J.M.; Barr, S.; Bousquet, F.; Butler, C.; Evans, L.; Marshall, N.; Quinn, T. Empathy, place and identity interactions for sustainability. Glob. Environ. Chang. 2019, 56, 11-17. [CrossRef]

60. Fawcett, D.; Pearce, T.; Ford, J.D.; Archer, L. Operationalizing longitudinal approaches to climate change vulnerability assessment. Glob. Environ. Chang. 2017, 45, 79-88. [CrossRef]

61. Charnley, S.; Carothers, C.; Satterfield, T.; Levine, A.; Poe, M.R.; Norman, K.; Donatuto, J.; Breslow, S.J.; Mascia, M.B.; Levin, P.S.; et al. Evaluating the best available social science for natural resource management decision-making. Environ. Sci. Policy 2017, 73, 80-88. [CrossRef]

62. Bandyopadhyay, S.; Younas, J. Poverty, political freedom, and the roots of terrorism in developing countries: An empirical assessment. Econ. Lett. 2011, 112, 171-175. [CrossRef]

63. Hargrove, M.D. Mapping the "social field of whiteness": White racism as habitus in the city where history lives. Transform. Anthropol. 2009, 17, 93-104. [CrossRef]

64. Thomas, J.M. The impact of corporate tourism on Gullah blacks: Notes on issues of employment. Phylon 1980, 41, 1-11. [CrossRef]

65. McArdle, K. Multiple case study of nonprofit partnerships in North Carolina's coastal state parks. Coast. Manag. 2020, 48, 38-56. [CrossRef]

66. Mbaiwa, J.E. Community-based tourism and the marginalized communities in Botswana: The case of the Basarwa in the Okavango Delta. In Indigenous Tourism: The Commodification and Management of Culture; Ryan, C., Aicken, M., Eds.; Elsevier: Oxford, UK, 2005; pp. 87-109.

67. Powell, R.B.; Ramshaw, G.P.; Ogletree, S.S.; Krafte, K. Can heritage resources highlight changes to the natural environment caused by climate change? Evidence from the Antarctic tourism experience. J. Herit. Tour. 2016, 11,71-87. [CrossRef] 
68. Bigaran, F.; Mazzola, A.; Stefani, A. Enhancing territorial capital for developing mountain areas: The example of Trentino and its use of medicinal and aromatic plants. Acta Geogr. Slov. 2013, 53, 379-391. [CrossRef]

69. Tao, T.C.H.; Geoffrey, W. Tourism for marginal groups: Tourism as a livelihood strategy in an indigenous community in Taiwan. In Proceedings of the BEST Education Network Think Tank VIII, Sustaining Quality of Life through Tourism, Izmir, Turkey, 24-27 June 2008.

70. Hunt, K.J.; Kistner-Griffin, E.; Spruill, I.; Teklehaimanot, A.A.; Garvey, W.T.; Sale, M.; Fernandes, J. Cardiovascular risk in Gullah African Americans with high familial risk of type 2 diabetes mellitus: Project SuGAR. South. Med. J. 2014, 107, 607-614. [CrossRef]

71. Marlow, N.M.; Slate, E.H.; Bandyopadhyay, D.; Fernandes, J.K.; Leite, R.S. Health insurance status is associated with periodontal disease progression among Gullah African-Americans with type 2 diabetes mellitus. J. Public Health Dent. 2011, 71, 143-151. [CrossRef]

72. Gilkeson, G.S.; James, J.A.; Kamen, D.L.; Knackstedt, T.J.; Maggi, D.R.; Meyer, A.K.; Ruth, N.M. The United States to Africa lupus prevalence gradient revisited. Lupus 2011, 20, 1095-1103. [CrossRef] [PubMed]

73. Kamen, D.L.; Barron, M.; Parker, T.M.; Shaftman, S.R.; Bruner, G.R.; Aberle, T.; James, J.A.; Scofield, R.H.; Harley, J.B.; Gilkeson, G.S. Autoantibody prevalence and lupus characteristics in a unique African American population. Arthritis Rheum. 2008, 58, 1237-1247. [CrossRef] [PubMed]

74. Fatorić, S.; Seekamp, E. Evaluating a decision analytic approach to climate change adaptation of cultural resources along the Atlantic Coast of the United States. Land Use Policy 2017, 68, 254-263. [CrossRef]

75. Gregory, R.; Easterling, D.; Kaechele, N.; Trousdale, W. Values-based measures of impacts to indigenous health. Risk Anal. 2016, 36, 1581-1588. [CrossRef]

76. Mattsson, B.J.; Arih, A.; Heurich, M.; Santie, S.; Štemberk, J.; Vacika, H. Evaluating a collaborative decision-analytic approach to inform conservation decision-making in transboundary regions. Land Use Policy 2019, 83, 282-296. [CrossRef]

77. Magistro, J.; Roncoli, C. Anthropological perspectives and policy implications of climate change research. Clim. Res. 2001, 19, 91-96. [CrossRef]

78. Smith, J.P. Cultural preservation of the Sea Island Gullah: A Black social movement in the post-civil rights era. Rural Sociol. 1991, 56, 284-298. [CrossRef]

(C) 2020 by the authors. Licensee MDPI, Basel, Switzerland. This article is an open access article distributed under the terms and conditions of the Creative Commons Attribution (CC BY) license (http://creativecommons.org/licenses/by/4.0/). 